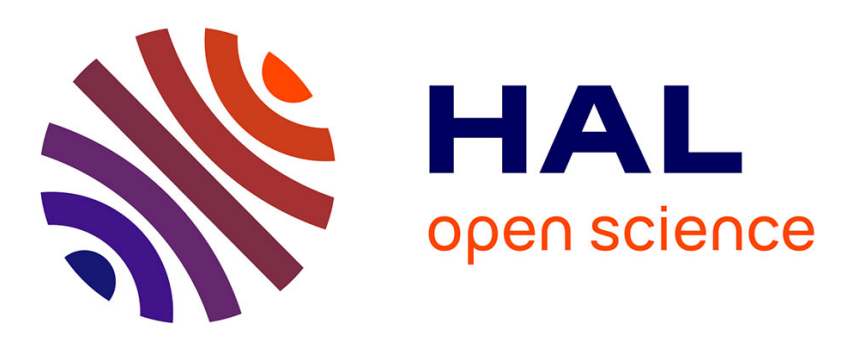

\title{
Colonisation of fish and crabs of wave energy foundations and the effects of manufactured holes - a field experiment
}

\author{
Olivia Langhamer, Dan Wilhelmsson
}

\section{- To cite this version:}

Olivia Langhamer, Dan Wilhelmsson. Colonisation of fish and crabs of wave energy foundations and the effects of manufactured holes - a field experiment. Marine Environmental Research, 2009, 68 (4), pp.151. 10.1016/j.marenvres.2009.06.003 . hal-00505736

\section{HAL Id: hal-00505736 \\ https://hal.science/hal-00505736}

Submitted on 26 Jul 2010

HAL is a multi-disciplinary open access archive for the deposit and dissemination of scientific research documents, whether they are published or not. The documents may come from teaching and research institutions in France or abroad, or from public or private research centers.
L'archive ouverte pluridisciplinaire HAL, est destinée au dépôt et à la diffusion de documents scientifiques de niveau recherche, publiés ou non, émanant des établissements d'enseignement et de recherche français ou étrangers, des laboratoires publics ou privés. 


\section{Accepted Manuscript}

Colonisation of fish and crabs of wave energy foundations and the effects of manufactured holes - a field experiment

Olivia Langhamer, Dan Wilhelmsson

PII: S0141-1136(09)00064-6

DOI: 10.1016/j.marenvres.2009.06.003

Reference: MERE 3341

To appear in: Marine Environmental Research

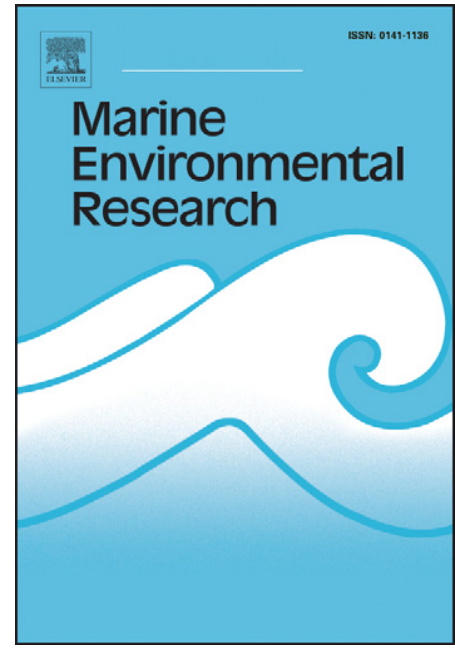

Received Date: $\quad 18$ March 2009

Revised Date: 29 May 2009

Accepted Date: $\quad 1$ June 2009

Please cite this article as: Langhamer, O., Wilhelmsson, D., Colonisation of fish and crabs of wave energy foundations and the effects of manufactured holes - a field experiment, Marine Environmental Research (2009), doi: 10.1016/j.marenvres.2009.06.003

This is a PDF file of an unedited manuscript that has been accepted for publication. As a service to our customers we are providing this early version of the manuscript. The manuscript will undergo copyediting, typesetting, and review of the resulting proof before it is published in its final form. Please note that during the production process errors may be discovered which could affect the content, and all legal disclaimers that apply to the journal pertain. 
Colonisation of fish and crabs of wave energy foundations and the effects of manufactured holes - a field experiment

Olivia Langhamer $^{(1,2)}$ and Dan Wilhelmsson ${ }^{(3)}$

(1) Department of Animal Ecology. Uppsala University, Norbyvägen 18D, 75239 Uppsala, Sweden. E.mail: olivia.langhamer@ebc.uu.se

(2) Dept. of Swedish Centre for Renewable Electric Energy Conversion, Division for Electricity and Lightning Research, Institution of Engineering Sciences, Uppsala University, Box 534, S-75121 Uppsala,

(3) Department of Zoology, Stockholm University, 10691 Stockholm, Sweden. E-mail: E-mail: dan.wilhelmsson@zoologi.su.se 


\begin{abstract}
Several Western European countries are planning for a significant development of offshore renewable energy along the European Atlantic Ocean coast, including many thousands of wave energy devices and wind turbines. There is an increasing interest in articulating the added values of the creation of artificial hard bottom habitats through the construction of offshore renewable energy devices, for the benefit of fisheries management and conservation. The Lysekil Project is a test park for wave power located about $100 \mathrm{~km}$ north of Gothenburg at the Swedish west coast. A wave energy device consists of a linear wave power generator attached to a foundation on the seabed, and connected by a wire to a buoy at the surface. Our field experiment examined the function of wave energy foundations as artificial reefs. In addition, potentials for enhancing the abundance of associated fish and crustaceans through manufactured holes of the foundations were also investigated. Assemblages of mobile organisms were examined by visual censuses in July and August 2007, 3 months after deployment of the foundations. Results generally show low densities of mobile organisms, but a significantly higher abundance of fish and crabs on the foundations compared to surrounding soft bottoms. Further, while fish numbers were not influenced by increased habitat complexity (holes), it had a significantly positive effect on quantities of edible crab (Cancer pagurus), on average leading to an almost five-fold increase in densities of this species. Densities of spiny starfish (Marthasterias glacialis) were negatively affected by the presence of holes, potentially due to increased predator abundance (e.g. C. pagurus). These results suggest a species-specific response to enhanced habitat complexity.
\end{abstract}

Key words: artificial reefs, coastal zone management, disturbance, fisheries, habitat complexity, habitat enhancement, wave power. 


\section{Introduction}

A number of countries are planning for a significant development of offshore renewable energy along for example the European Atlantic Ocean coast, including many thousands of wave energy devices and wind turbines forming energy farms that will require areas of several square kilometres each (Oxley, 2006; Callaway, 2007, Cruz, 2008, IEA, 2008). Nature conservation concerns with respect to offshore energy development commonly centre around adverse effects of habitat and hydrodynamic alterations, noise, and electromagnetic fields on the marine environment (e.g. Gill, 2005; Wahlberg and Westerberg, 2005; Petersen and Malm, 2006; Broström, 2008; Tyack, 2008). At the same time, there is an increasing interest in articulating the potentially positive aspects of creating artificial hard bottom habitats through the construction of offshore renewable energy devices (Wilhelmsson et al. 2006a; Langhamer et al., 2009; Wilson and Elliot, 2009). The foundations of the energy devices will exclude trawling activities from the claimed area, and will also constitute "secondary artificial reefs" (Pickering et al., 1998) for fish and invertebrates and may also function as fish aggregating devices (FADs) (Wilhelmsson et al., 2006a; Fayram and de Risi, 2007; Wilhelmsson and Malm, 2008; Langhamer et al., 2009). These aspects of local impacts of offshore renewable energy development may, in theory, be beneficial for fisheries management and species conservation.

Availability of shelter from predation may be a demographic bottleneck for several species, such as European lobster H. gammarus, and to some extent edible crab C. pagurus (e.g. Jensen et al., 1994; Pickering and Whitmarsh, 1997; Ackefors, 2005). Deployment of wave and wind power foundations could thus be hypothesised not only to aggregate marine biota and decrease fishing mortality, but also to significantly enhance biomass production of these shellfishes at local scale. By considering certain habitat preferences of marine organisms in the design of the structures, given acceptable costs, abundance and diversity of associated species could be enhanced. Commercially important or threatened species could be specially catered for where desired (e.g. Nakamura, 1985; Bortone et al., 1994; Kawasaki et al., 2002). For instance, the structural complexity of the foundations could be increased at relevant scales, to enhance the abundance, diversity and biological productivity of motile macrofauna. This would primarily be coupled to enhanced shelter properties, the creation of physical barriers and compartments of the habitat, and various behavioural responses (Risk, 1972; Luckhurst and Luckhurst, 1978; Hixon and Beets, 1989; Chabanet et al., 1997; Friedlander 
and Parrish, 1997; Bortone et al. 1994; Potts and Hulbert, 1994; Spieler et al., 2001). For standardized examinations of the influence of structural complexity at various scales and on different species on both natural and artificial reefs, manufactured or already existing holes of different numbers, densities, sizes, and combinations have commonly been considered (e.g. Hixon and Beets, 1989; Friedlander and Parrish, 1998; Sherman et al., 2002).

There is, however, a great variability in taxon- and age specific responses of fishes to the deployment of differently designed artificial reefs, and regional ecological and environmental factors strongly influence the function of an artificial reef (Hueckel et al., 1989; Bohnsack et al., 1991; Baine, 2001). The information base for optimising artificial reef design to provide the specific habitat requirements of desired species and age groups, or enhancement of fish biomass production is generally weak (Seaman and Sprague, 1991; Baine, 2001; but see Nakamura's (1985) review on research in Japan). Invertebrates, fish, and algae may also be negatively affected by the presence of an artificial reef, through increased predation pressure in its vicinity (Davis et al., 1982; Kurz, 1995; Jordan et al., 2005).

Since 2005, the Lysekil wave energy research site, located near the city of Lysekil on the Swedish west coast, is being developed. Both technical and environmental studies are carried out within the project, in order to evaluate the wave energy converter concept for further commercialisation. One wave power unit consists of a steel buoy on the surface that drives a translator in a direct-driven linear generator moored to a concrete foundation on the seabed (Fig.1). This type of device functions at water depths ranging from $20 \mathrm{~m}$ to $100 \mathrm{~m}$. The Lysekil research site covers about $40000 \mathrm{~m}^{2}$ and currently comprises 29 wave power devices; 3 with generators and 26 without generators for initial ecological studies (Leijon et al., 2009).

Predictions of the influence of the wave power foundations on the distribution of macrobenthos are uncertain. There are only a few examples of artificial reef studies in cold temperate waters (Baine, 2001), and even fewer have included experiments with different structural factors or, additionally, been conducted at the depths below $15 \mathrm{~m}$, at higher latitudes (but see Wilhelmsson et al., 2006b; Langhamer et al., 2009). A pilot study by Langhamer and colleagues (2009), conducted in the Lysekil wave energy park, indicated a sparse colonisation by fish while edible crabs seemed more affected by the hard substrata deployed. However, the number of foundations quantitatively surveyed was low $(n=3)$, providing weak evidence for the conclusions. 
The purpose of this study was to examine to what extent added protruding, but non-complex, hard substrate, through the deployment of wave power foundations on bare sandy bottoms, affect local distribution patterns of fish and motile invertebrates. Effects of low cost enhancements of shelter availability and compartment through holes in the foundations were also investigated. We hypothesised that wave energy foundation would aggregate fish and crustaceans, and that holes in the foundations would further enhance their abundance.

\section{Methods}

\subsection{Study site and experimental design}

The Lysekil research site is situated on the Swedish west coast, about $100 \mathrm{~km}$ north of Gothenburg, near Lysekil (Fig. 2). The site is located $2 \mathrm{~km}$ offshore between a northern $\left(58^{\circ} 11^{\prime} 850^{\prime \prime} \mathrm{N}, 1^{\circ} 22^{\prime} 460^{\prime \prime} \mathrm{E}\right)$ and a southern $\left(58^{\circ} 11^{\prime} 630^{\prime \prime} \mathrm{N}, 11^{\circ} 22^{\prime} 460^{\prime \prime} \mathrm{E}\right)$ marker. The shoreline of the area is characterised by rocky slopes covered by algae, with sandy and muddy bottoms below the rocky outcrops (Cato and Kjellin, 2008). The site is a flat sandy bottom at $25 \mathrm{~m}$ depth, with little relief. The area is exposed to predominantly westerly winds and waves and the tidal range is about $0.3 \mathrm{~m}$ (Johannesson, 1989). The temperature of the surface water is in the range of $15-20^{\circ} \mathrm{C}$ in the summer and $0-2{ }^{\circ} \mathrm{C}$ in the winter. Average salinity is $25 \%$, and covering ice occurs on average every forth year (Åberg, 1992).

In May 2005, the first experimental set-up, including five wave power devices (without generators), was launched in the Lysekil research site on otherwise featureless soft bottom. The scope of the deployment of these devices was to conduct pilot-studies on environmental impacts and colonisation patterns of marine organisms on both wave power buoys and foundations (Langhamer et al., 2009). In spring 2006, the first wave energy converter (WEC) was deployed in the research site. 
In April 2007, another 21 wave power devices were launched, and these were used in the present experiment. The foundations measured $3 \mathrm{~m}$ in diameter, were $1 \mathrm{~m}$ high, and weighed $10 \mathrm{t}$ each. The distance between modules was 15-20 m, allowing access by research vessels and for waves to gain a certain fetch approaching the next wave power buoy. Eleven of the foundations were each perforated with 26 rectangular holes, $12 \mathrm{~cm}$ x $15 \mathrm{~cm}$ x $30 \mathrm{~cm}$ (width $\mathrm{x}$ height $\mathrm{x}$ depth). Thirteen of the holes were made in the lower edge of the structure, so that the seabed constituted the floor of the holes, while 13 holes were drilled on the vertical side of the foundation, $50 \mathrm{~cm}$ above the seabed (Fig. 3). On the 10 remaining foundations no holes were made. The foundations were positioned so that, generally, every second had holes (Fig. 2).

Eight meters from each foundation (in haphazard directions), bottoms of the same total area as on and around the foundations $\left(12 \mathrm{~m}^{2}\right)$ were examined for comparison to the newly added hard bottom habitats. These control areas comprised flat bare sandy bottoms.

\subsection{Survey methods}

The 21 wave power foundations added in 2007 were sampled once during July - August 2007 by SCUBA-diving, 2-3 months after deployment. Fish and crustaceans associated with the modules and in controls were recorded through visual censuses on the structures, including the holes where present, and on the surrounding bottom within $1 \mathrm{~m}$ distance (i.e. $5 \mathrm{~m}^{2}$ sand bottom). On the foundations, the top of the structure was surveyed first. After that, the sides, the holes, and the adjacent bottom were surveyed by slowly moving clockwise around the foundation. The controls were censused in same way as the foundations, although these were predominantly two-dimensional (flat sandy bottom). One census, of either a foundation or a control took approximately 8 minutes

Two species of Pomatoschistus spp. are common on the Swedish west coast; sand goby (P. minutus) and common goby (P. microps). It is difficult to distinguish between them during in situ surveys. At the depths surveyed here, $25 \mathrm{~m}$, most of the Pomatoschistus spp. are likely to be P. minutus (Jansson et al., 1985; Thorman and Wiederholm, 1986). Consequently, only the name $P$. minutus was used although our data could include some $P$. microps. Flatfishes were recorded as Pleuronectidae, and the two sculpins, sea scorpion (Taurulus bubalis) and bullrout (Myoxocephalus scorpius), were referred to as cottids. 


\subsection{Data analyses}

Comparisons of numbers of fish, shellfish, and other invertebrates were made where frequencies of occurrence and abundances of species or taxa were sufficiently large. Comparisons between reef modules and controls were made using Wilcoxon's Matched Pairs Test. Shoals of juvenile fish were excluded in the data analyses to avoid skewness of data. Wilcoxons' was also used to compare the occupancy of the holes $50 \mathrm{~cm}$ above the bottom with that of the holes along the bottom. For comparisons of abundance data between noncomplex foundations and foundations with holes, Mann-Whitney U-tests were performed.

\section{Results}

A total of 17 taxa of fish (8), crustaceans (6), and echinoderms (3), were recorded in the survey (Table 1). Eight species of fish were recorded on the foundations, while three species were noted in the controls (Table 1). Although generally low, fish abundance was significantly higher on the foundations than in the controls (Wilcoxon's, $p=0.02$, Fig. 4). Only a few fish used the holes in the foundations, and no effect of holes on fish abundance was shown (Mann-Whitney, $p=0.95$ ). No fish was found in the holes situated $0.5 \mathrm{~m}$ above the bottom (Table 2). Species-specific affinity for holes was, however, preliminary indicated. Three species of fish occupied the holes, albeit only along the bottom; Atlantic cod Gadus morhua (two of five recorded adult specimens), bullrout (one of two specimens recorded), and rock gunnel Pholis gunnellus (one of three recordings). Both cod recorded on the complex foundations were inside the holes.

Abundance of edible crab (Cancer pagurus), on the other hand, was positively affected both by the foundations without holes (Wilcoxon's, $p=0.03$, Fig. 5), and by the presence of holes when comparing the non-complex foundations with the perforated ones (Mann-Whitney, $p<$ 0.01, Fig. 5). C. pagurus used the holes situated $0.5 \mathrm{~m}$ above the bottom more frequently than it used the holes along the bottom (Wilcoxon's, $p=0.03$, Fig. 5, Table 2). In addition, $C$. pagurus were often associated with steel bolts protruding from the top of the foundations. One European lobster (Homarus gammarus) and one Norwegian lobster (Nephrops norvegicus) were found in the survey. The lobsters resided in dug out cavities under the foundations. 
The presence of the artificial hard substrate did not seem to influence numbers of hermit crab (Pagurus bernhardus), great spider crab (Hyas araneus), common starfish (Asterias rubens), and masked crab (Corystes cassivalurus), although, at least for the latter three species, only a few individuals were recorded as a whole. The foundations attracted the spiny seastar Marthasterias glacialis, however, with an average of 0.8 (1.2 \pm standard deviation) individuals on the foundations while the species was not represented at all in the controls (Table 1). The abundance of M. glacialis was significantly higher on the non-complex foundations compared to the ones with holes (Mann-Whitney, $p=0.03$ ). Densities of the sand dwelling echinoderm Astropecten irregularis (sand star) were, less surprisingly, negatively affected by the hard substrate added (Wilcoxon's, $p<0.01$ ).

\section{Discussion}

Apart from the holes, the wave power foundations had low structural complexity. The reef modules, however, added relief to the seabed, and the steep walls of the foundations may offer a certain degree of shelter by eliminating angles of attack by predators and provide lee from currents. The foundations also serve as substrates for epibiota (Langhamer et al., 2009), as well as entrap detritus, and thereby enhance organic production (Wolfson et al., 1979). They may also be used as cues or reference points for spatial orientation for fish (e.g. Nakamura, 1985). A number of fish species, including codfishes, wrasses, and flatfishes have been shown to associate with high relief structures of comparably low complexity during parts or most of their life cycles (Gregory and Anderson, 1997; Light and Jones, 1997; Stanley et al., 2002; Johnson et al., 2003; Cote et al., 2004; Wilhelmsson et al., 2006b).

The present study demonstrated scale dependent as well as species-specific responses to habitat manipulations. Although fish abundance was low compared to other artificial reefs and natural rocky bottoms in the same region (e.g. Wilhelmsson et al., 2006b; Stål et al., 2007), it was positively affected by the enhanced habitat heterogeneity at the scale of meters, achieved by the deployment of protruding hard substrate on an otherwise featureless soft bottom. The finer scale complexity provided by the holes, on the other hand, did not seem, at least during day time, to be utilised by most fishes to any significant degree. No effects of the holes on fish abundance were shown, and our second hypothesis was thus not supported in terms of fish. Edible crab (Cancer pagurus), on the contrary, commonly used the holes for shelter, and 
their carapace width generally matched the size of the holes well. Thus, while the effect of foundations with no holes on crab abundance was relatively weak, structural complexity at the scale of the holes showed to have a strong influence. It is also worth noting that C. pagurus showed a strong affinity for the protruding steel bolts that probably offered a certain degree of shelter and points of reference.

Colonisation of artificial reefs by reef dwelling fish is commonly relatively rapid (i.e. a few days to months), as was also shown in an experiment in the same region as the present study site (Wilhelmsson et al., 2006b). However, on the reef units in this experiment, species often dominating rocky bottoms in the area, such as cottids and wrasses (Pihl and Wennhage, 2002; Stål et al., 2007), were rare or absent. On other wave power foundations in the same area, similarly low numbers of these species were consistently recorded over three summer seasons (2006-2008, Langhamer et al., 2009). This indicates that, although this survey was conducted before the major period for settlement of year-juveniles of for example C. rupestris (i.e. August-September, Hilldén, 1981), abundances and species numbers may not increase notably with time.

The nearest natural reef was situated $200 \mathrm{~m}$ away, and the reef units may have been too isolated for the sustenance of sufficient colonization rates of adult fish to maintain sizable assemblages. It is more likely, however, that the reefs are located too deep and are too devoid of refuge at relevant scale (e.g. smaller holes, macroalgae) both for aggregation of adult fish and direct recruitment and survival of juvenile fish of any quantities (Shulman, 1984; Hixon and Beets, 1989; Levin, 1993; Stål et al., 2007). Furthermore, some fishes have been shown to avoid holes with only one opening, due to the limited escape options and water exchange (Dean, 1983; Spieler et al., 2001). In addition, a portion of the holes was occupied by sizable C. pagurus. Many species, on the other hand, migrate to deeper waters in the autumn, when water temperature drops (Hilldén, 1981; Jansson et al., 1985; Pihl and Wennhage, 2002). It could, thus, be relevant to investigate fish assemblages on the reef units during winter months, although weather conditions make surveys more difficult and costly.

In this study, as well as in the pilot study by Langhamer with colleagues (2009), European lobsters (Homarus gammarus) were only present in cavities under the foundations. No lobster used holes for shelter. The scope for manipulations of the design of wave power foundations to enhance densities of associated lobsters will be matter of assessing the costs relative to 
benefits. For potential application in wave power development, a number of suggestions and hypotheses regarding shelter preferences and habitat optimisation for different species of lobsters, particularly for $H$. gammarus, would be worthwhile to develop or verify, including for example size, shape and number of shelter entrances, optimal size distribution and density of shelters, and preferred substrate composition (e.g. Spanier, 1994; Hernkind et al., 1997; Jensen et al., 2000 and references therein; Spieler et al., 2001; Miller et al., 2006)

C. pagurus clearly favoured the holes on the side of the foundations, $50 \mathrm{~cm}$ above the seabed, over the holes along the bottom. The reasons for this preference are unclear as knowledge on behaviour of $C$. pagurus at microhabitat level is very limited. Speculations may include: less sediment build-up compared to the holes along the bottom and thus less maintenance work required, less disturbance from lobsters (Richards and Cobb, 1986), and enhanced protection from predators. The negative effect on abundance of sand stars (Astropecten iregularis) of the foundations is likely to be simply due to the loss of soft bottom area. Further, the suggested adverse influence of structural complexity on densities of the hard-bottom dwelling spiny starfish (Marthasterias glacialis) is potentially a result of the significantly increased predator abundance (i.e. C. pagurus) on the foundations with holes (Verling et al., 2003).

Once sufficient shelter has been provided, one limiting factor for numbers of associated fish and crustaceans could become food supply on and in the vicinity of the artificial structures. Blue mussels (Mytilus edulis) dislodged from the energy converter buoy at the surface could constitute an importance source of prey for C. pagurus and H. gammarus. During subsequent diving on the foundations in 2008, many C. pagurus and hermit crabs (Pagurus bernardus) were observed preying upon blue mussels scattered in numerous lumps on and around the foundations. The buoys, $25 \mathrm{~m}$ above, are thus integral parts of these artificial reef systems.

\section{Conclusion}

The present experiment, along with earlier studies, provides some initial indications of how wave power foundations, as well as added structural components, could both enhance abundances of associated fish and invertebrates and have adverse effects on local numbers of certain species. The value of habitat enhancement efforts through structural design of wave foundations would benefit from additional and more comprehensive experimental studies 
targeting preferences of specific species or assemblages. In addition, the carrying capacity in terms of prey availability on and around these artificial habitats under different circumstances should be investigated, including effects of aggregations of predators on abundance and diversity of associated and surrounding biota.

\section{Acknowledgements:}

The authors wish to thank M. Asplund, J. Bjelvemark, K. Haikonen, M. Persson and other who assisted in the field. We also thank the staff at Kristineberg Marine Research Station for their helpfulness and hospitality, and the Ångström Laboratory for the construction of the wave power devices. S. Nylin made valuable comments on the manuscript, and P. Moxnes and H. Ackefors advised on shellfish behaviour. This research was supported by the Swedish Energy Agency, Draka Cable AB, Vattenfall AB, Research Foundation Gothenburg Energy AB, Göran Gustavsson Research Foundation, Vargöns Research Foundation, Falkenberg Energy AB, Stockholm's Marine Research Foundation, Hoffsten Foundation, Futura Foundation and Inez Johansson Foundation, and Fortum AB.

\section{References}

Åberg, P., 1997. A demographic study of two populations of the seaweed Ascophyllum nodosum. Ecology 73(4), 1473-1487.

Ackefors, H., 2005. Kräftdjur I hav och sjöar (in Swedish). Kivikgårdens förlag, Sweden. ISBN 91-973515-4-7. 384 p.

Anderson, T.W., DeMartini, E.E., Roberts, D.A., 1989. The relationship between habitat structures, body size and distribution of fishes at a temperate artificial reef. Bulletin of Marine Science 44, 681-697.

Baine, M., 2001. Artificial reefs: a review of their design, application, management and performance. Ocean and Coastal Management 44, 241-259. 
Bohnsack, J.A., Johnson, D.L., Ambrose, R.F., 1991. Ecology of Artificial Reef Habitats and Fishes. In: Seaman, W. and Sprague, L. M. Artificial habitats for marine and freshwater fisheries, 61-84. Academic Press Inc., San Diego, California.

Bortone, S.A., Martin,T., Bundrick C.M., 1994. Factors affecting fish assemblage development on a modular artificial reef in a northern Gulf of Mexico estuary. Bulletin of Marine Science 55, 319-332.

Broström, G., 2008. On the influence of large wind farms on the upper ocean circulation. Journal of Marine Systems 74, 585-591.

Callaway, E., 2007. To catch a wave. Nature 450, 156-159.

Cato, I., Kjellin, B., 2008. Maringeologiska undersökningar vid vågkraftsanläggning utanför Islandsberg, Bohuslän. Sveriges geologiska undersökning, Uppsala, SGU-rapport 2008:10

Chabanet, P. Ralambondrainy, H., Amanieu, M., Faure, G., Galzin, R., 1997. Relationships between coral reef substrata and fish. Coral Reefs 16, 93-102.

Chandler, R., Sanders, R.M., Landry, A.M., 1985. Effects of three substrate variables on two artificial reef fish communities. Bulletin of Marine Science 37, 129-142.

Cote, D., Moulton S., Frampton P.C.B., Scruton, D.A., McKinley R.S., 2004. Habitat use and early winter movements by juvenile Atlantic cod in a coastal area of Newfoundland. Journal of Fish Biology 64, 665-679.

Cruz, J., 2008. Ocean wave energy. Current status and future perspectives. Springer, BerlinHeidelberg. ISBN: 978-3-540-74894.

Davis, N., VanBlaricom, G.R., Dayton, P.K. 1982. Man-made structures on marine sediments: Effects on adjacent benthic communities. Marine Biology 70, 295-303. 
Dean, L., 1983. Undersea oases made by man: artificial reefs create new fishing grounds. Oceans 26, 27-29.

Fayram, A.H., de Risi, A., 2007. The potential compatibility of offshore wind power and fisheries: An example using bluefin tuna in the Adriatic Sea. Ocean and Coastal Management 50, 597-605.

Friedlander, A.M., Parrish, J.D., 1998. Habitat characteristics affecting fish assemblages on a Hawaiian coral reef. Journal of Experimental Marine Biology and Ecology 224, 1-30.

Gill, A.B., 2005. Offshore renewable energy: ecological implications of generating electricity in the coastal zone. Journal of Applied Ecology 42, 605-615.

Gregory, R.S, Anderson J.T., 1997. Substrate selection and use of protective cover by juvenile cod Gadus morhua in inshore waters of Newfoundland. Marine Ecology Progress Series 146, 9-20.

Griggs, R.W., 1994. Effects of sewage discharge, fishing pressure and habotat complexity on coral ecosystems and reef fishes in Hawaii. Marine Ecology Progress Series 103, 25-34.

Hernkind, W.F., Butler, M.J., Hunt, J.H., 1997. Can artificial habitats that mimic natural structures enhance recruitment of Caribbean spiny lobster. Fisheries 22, 24-27.

Hilldén N-O., 1981. Territoriality and reproductive behavior in the Goldsinny, Ctenolabrus rupestris L. Behavioral Processes 6, 207-221.

Hixon, M.A., Beets, P.J., 1989. Shelter characteristics and Caribbean fish assemblages: experiments with artificial reefs. Bulletin of Marine Science 44, 666-680.

Hueckel, G.J., Buckley, R.M., Benson, B.L., 1989. Mitigating rocky habitat loss using artificial reefs. Bulletin of Marine Science 44, 913-922.

IEA (International Energy Agency), 2008. Wind Energy Annual Report 2007. IEA, Paris, pp 286, ISBN 0-9786383-2-8. 
Jansson, B-O., Aneer G., Nellbring S., 1985. Spatial and temporal distribution of the demersal fish fauna in a Baltic archipelago as estimated by SCUBA census. Marine Ecology Progress Series 23, 31-43.

Jensen, A., Collins, K.J., Free, E.K., Bannister, C.A., 1994. Lobster (Homarus gammarus) movement on an artificial reef: the potential use of artificial reefs for stock enhancement. Crustaceana 67, 198-212.

Jensen, A., Wickins, J., Bannister, C., 2000. The potential use of artificial reefs to enhance lobster habitat. In: Jensen, A.C., Collins, K.J., Lockwood, A.P.M. (eds.). Artificial reefs in European seas, 379-402. Kluwer Academic Publishers, Dordrecht, The Netherlands. ISBN: 07923-5845-7.

Johannesson, K., 1989. The bare zone of the Swedish rocky shores: why is it there? Oikos 54, $77-86$.

Johnson, S.W., Murphy, M.L., Csepp, D.J., 2003. Distribution, habitat, and behavior or rockfishes, Sebastes spp., in nearshore waters of southeastern Alaska: observations from a remotely operated vehicle. Environmental Biology of Fishes 66, 259-270.

Jordan, K.K.B., Gilliam, D.S., Spieler, R.E., 2005. Reef fish assemblage structure affected by small-scale spacing and size variations of artificial patch reefs. Journal of Experimental Marine Biology and Ecology 326, 170-186.

Kawazaki, H., Sano, M., Shibuno, T., 2002. The relationship between habitat physical complexity and recruitment of the coral reef damselfish, Pomacentrus amboinensis: an experimental study using small-scale artificial reefs. Ichtyological Research 50, 73-77.

Kurz, R.C., 1995. Predator-prey interactions between gray triggerfish (Balistes capriscus gmelin) and a guild of sand dollars around artificial reefs in the northeastern Gulf-of-Mexico. Bulletin of Marine Science 56,150-160. 
Langhamer, O., Wilhelmsson, D., Engström, J., 2009. Artificial reef effect and fouling impacts on offshore wave power foundations and buoys - a pilot study. Estuarine, Coastal and Shelf Science. DOI: 10.1016/j.ecss.2009.02.009. Available online.

Leijon, M., Boström, C., Danielsson, D., Gustafsson, S., Haikonen, K., Langhamer, O., Strömstedt, E., Stålberg, M., Sundberg, J., Svensson,O., Turberg, S., Waters, R., 2008. Wave energy from the North Sea: Experiences from the Lysekil Research Site. Survey in Geophysics. DOI: 10.1007/s10712-008-9047-x.

Levin, P.S., 1993. Habitat structure, conspecific presence and spatial variation in the recruitment of a temperate reef fish. Oecologia 94, 176-185.

Light, PR., Jones, GP., 1997. Habitat preference in newly settled coral trout (Plectropomus leopardus, Serranidae). Coral Reefs 16, 117-126.

Luckhurst, B.E., Luckhurst, K., 1978. Analysis of the influence of substrate variables on coral reef communities. Marine Biology 49, 317-323.

Miller, R.J, Sharp G.J., O'Brien, E.M., 2006. Laboratory experiments on artificial reefs for American lobsters. Journal of Crustacean Biology 26, 621-627.

Nakamura, M., 1985. Evolution of artificial reef concepts in Japan. Bulletin of Marine Science 37, 271-278.

Oxley, R., 2006. An overview of marine renewables in the UK: a synopsis of Michael Hay's presentation. Ibis 148, 203-205.

Petersen, K.J., Malm, T., 2006. Offshore windmill farms: threats or possibilities to the marine environment. Ambio 35, 29-34.

Pickering, H., Whitmarsh, D., 1997. Artificial reefs and fisheries exploitation: a review of the "Attraction versus production" debate, the influence of design and its significance for policy. Fisheries Research 31, 39-45. 
Pihl, L., Wennhage, H., 2002. Structure and diversity of fish assemblages on rocky and soft bottom shores on the Swedish west coast. Journal of Fish Biology 61, 148-166.

Potts, T.A., Hulbert, A.W., 1994. Structural influences of artificial and natural habitats on fish aggregations on Onslow Bay, North Carolina. Bulletin of Marine Science 55, 609-622.

Richards, R.A., Cobb, J.S., 1986. Competition for shelter between lobster (Homarus americanus) and Johah Brabs (Cancer borealis): effects of relative size. Canadian Journal of Fisheries and Aquatic Science 43, 2250-2255.

Risk, M.J., 1972. Fish diversity on a coral reef in the Virgin Islands. Atoll Research Bulletin $153,1-6$.

Seaman, W., Sprague, L.M., 1991. Artificial Habitat Practices in Aquatic Systems. In: Seaman, W. \& Sprague, L.M. Artificial habitats for marine and freshwater fisheries, 1-27. Academic Press, Inc. San Diego, California 92101.

Sherman, R.L., Gillian, D.S., Spieler, R.E., 2002. Artificial reef design; void space, complexity, and attractants. ICES Journal of Marine Science 59, S196-200.

Shulman, M.J., 1984. Resource limitation and recruitment patterns in a coral reef fish assemblage. Journal of Experimental Marine Biology and Ecology 74, 85-109.

Spanier, E., 1994. What are the characteristics of a good artificial reef for lobsters? Crustaceana 67, 173-186.

Speiler, R.E., Gilliam, D.S., Sherman, R.L., 2001. Artificial substrate and coral reef restoration: What do we need to know to now what we need. Bulletin of Marine Science 69, 1013-1030.

Stål, J., Pihl, L., Wennhage, H., 2007. Food utilisation by coastal fish assemblages in rocky and soft bottoms on the Swedish west coast: Inference for identification of essential fish habitats. Estuarine, Coastal and Shelf Science 71, 593-607. 
Stanley, R.D., Kieser, R., Hajirakar M., 2002. Three-dimensional visualisation of a widow rockfish (Sebastes entomelas) shoal over interpolated bathymetry. ICES Journal of Marine Science 59, 151-155.

Thorman, S., Wiederholm, A-M., 1986. Food, habitat and time niches in a coastal fish species assemblage in a brackish water bay in the Bothnian Sea, Sweden. Journal of Experimental Marine Biology and Ecology 95, 67-86.

Tyack, P.L., 2008. Implications for marine mammals of large-scale changes in the marine environment. Journal of Mammalogy 89, 549-558.

Verling, E., Crook, A.C., Barnes, D.K.A., Harrison, S.S.C., 2003. Structural dynamics of a sea-star (Marthasterias glacialis) population. Journal of the Marine Biological Association of the United Kingdom 83, 583-592.

Wahlberg, M., Westerberg, H., 2005. Hearing in fish and their reactions to sounds from offshore wind farms. Marine Ecology Progress Series 288, 295-309

Wilhelmsson, D., Malm, T., Öhman, M., 2006a. The influence of offshore wind power on demersal fish. ICES Journal of Marine Science 63, 775-784.

Wilhelmsson, D. Yahya, S., Öhman, M., 2006b. Effects of high relief structures on cold temperate fish assemblages: A field experiment. Marine Biology Research 2, 136-147.

Wilhelmsson, D., Malm, T., 2008. Fouling assemblages on offshore wind power plants and adjacent substrata. Estuarine, Coastal and Shelf Science 79, 459-466.

Wilson, J.C., Elliot, M. 2009. The habitat potential of offshore wind farms. Wind Energy 12, 203-212.

Wolfson, A., Van Blaricom, G., Davis, N., Lewbel, G.S., 1979. The marine life of an offshore oil platform. Marine Ecology Progress Series, 81-89. 


\section{Figure legend:}

Fig. 1. Wave energy park and technical description of the wave power devices developed in the Lysekil Project. (C) Centre for Renewable Electric Energy Conversion and Seabased Ltd, respectively.

Fig. 2. Location of study area and configuration of the experimental wave power foundations (not to scale). $\mathrm{H}=$ foundations with holes.

Fig. 3. Deployment of an experimental unit (i.e. wave power foundation) that has been perforated with 26 holes. Wave absorbing buoys can be seen in the background.

Fig. 4. Average fish abundance $( \pm \mathrm{SE})$ on foundations and controls. $*=p<0.05$

Fig. 5. Average number of ( $\pm \mathrm{SE}$ ) edible crabs (Cancer pagurus) on foundations with and without holes, and in controls. $*=p<0.05$

Fig. 6. Overview of microhabitat use by edible crabs (Cancer pagurus), illustrated by average $( \pm \mathrm{SE})$ number of recorded specimens in different categories of holes as well as on and around the foundations (outside holes). $*=p<0.05$ 
Table 1. Mean abundance of echinoderms, decapods, and fish recorded on wave power foundations without holes, with holes, on all foundations, and in the control areas.

\begin{tabular}{|c|c|c|c|c|c|}
\hline $\begin{array}{l}\text { Taxa } \\
\text { Common name } \\
\text { Echinoderms }\end{array}$ & Latin name & $\begin{array}{c}\text { Foundations } \\
\text { without holes }\end{array}$ & $\begin{array}{c}\text { Foundations } \\
\text { with holes }\end{array}$ & Foundations & Control \\
\hline Spiny seastar & Marthasterias glacialis & 1.4 & 0.18 & 0.76 & - \\
\hline Common starfish & Asterias rubens & 0.1 & 0.09 & 0.10 & 0.10 \\
\hline Sand star & Astropecten irregularis & 0.2 & - & 0.10 & 1.8 \\
\hline \multicolumn{6}{|l|}{ Decapods } \\
\hline Norwegian lobster & Nephrops norvegicus & - & 0.09 & 0.05 & \\
\hline European lobster & Homarus gammarus & - & 0.09 & 0.05 & \\
\hline Hermit crab & Pagurus bernardus & 0.9 & 0.82 & 0.86 & 1.52 \\
\hline Harbour crab & Liocarcinus depurator & 0.9 & 0.82 & 0.86 & 0.95 \\
\hline Edible crab & Cancer pagurus & 0.9 & 4.82 & 2.95 & - \\
\hline Great spider crab & Hyas araneus & 0.2 & 0.09 & 0.14 & 0.10 \\
\hline \multicolumn{6}{|l|}{ Fish } \\
\hline Cod & Gadus morhua & 0.3 & 0.18 & 0.24 & - \\
\hline Juvenile codfish & Gadidae & 0.3 & 0.09 & 0.19 & - \\
\hline Pipefish & Nerophis spp. & - & 0.09 & 0.05 & - \\
\hline Bullrout & Cottidae & 0.1 & 0.09 & 0.10 & - \\
\hline Goldsinny wrasse & Ctenolabrus rupestris & 0.1 & 0.09 & 0.10 & - \\
\hline Rock gunnel & Pholis gunnellus & 0.1 & 0.18 & 0.14 & - \\
\hline Sand goby & Pomatochistus minutus & 0.2 & - & 0.10 & 0.10 \\
\hline Dragonet & Callionymus spp. & 0.1 & 0.18 & 0.14 & 0.38 \\
\hline Flatfish & Pleuronectidae & 0.2 & - & 0.10 & 0.10 \\
\hline
\end{tabular}


Table 2. Total abundance of echinoderms, decapods, and fish recorded on foundations with holes, in the upper holes, and in the bottom holes.

\begin{tabular}{lccc}
\hline Taxa & \multicolumn{3}{c}{ Foundations with holes } \\
On & $\begin{array}{c}\text { Side } \\
\text { holes }\end{array}$ & $\begin{array}{c}\text { Bottom } \\
\text { holes }\end{array}$ \\
Echinoderms & 2 & - & - \\
Spiny seastar & 1 & - & - \\
Common starfish & - & - & - \\
Sand star & & & \\
& & & \\
Decapods & - & - & 1 \\
Norwegian lobster & - & - & 1 \\
European lobster & 8 & - & 1 \\
Hermit crab & 6 & - & 3 \\
Harbour crab & 3 & 33 & 17 \\
Edible crab & 1 & - & - \\
Great spider crab & & & \\
& & & \\
Fish & - & - & 2 \\
Cod & 1 & - & - \\
Juvenile codfish & 1 & - & - \\
Pipefish & - & - & 1 \\
Bullrout & 1 & - & - \\
Goldsinny wrasse & 1 & - & 1 \\
Rock gunnel & - & - & - \\
Sand goby & 2 & - & - \\
Dragonet & - & - & - \\
Flatfish & & & \\
\hline & & & \\
\hline
\end{tabular}



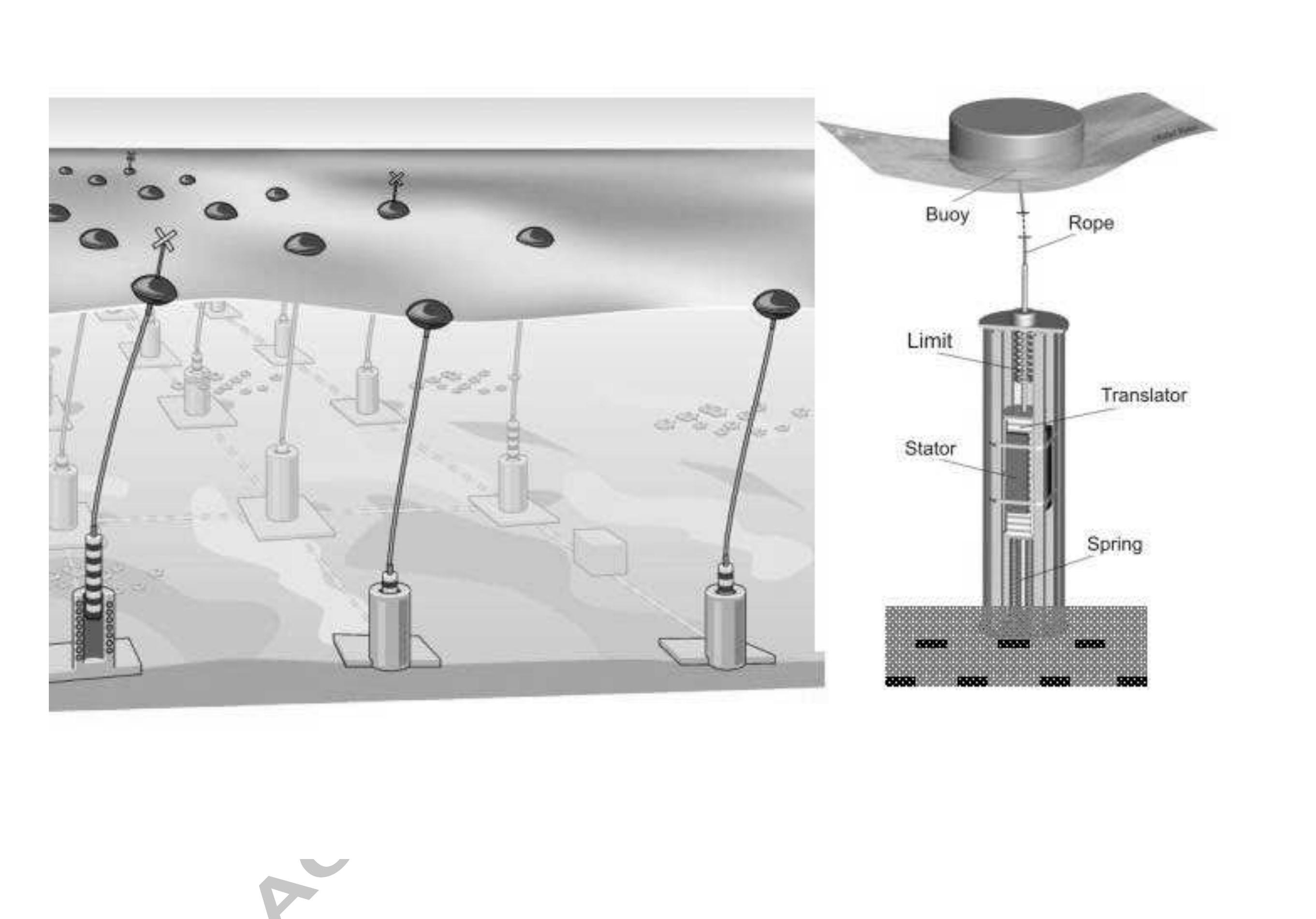

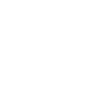

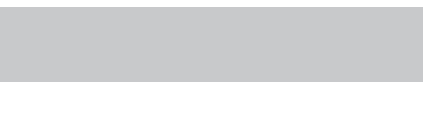

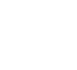

(n)
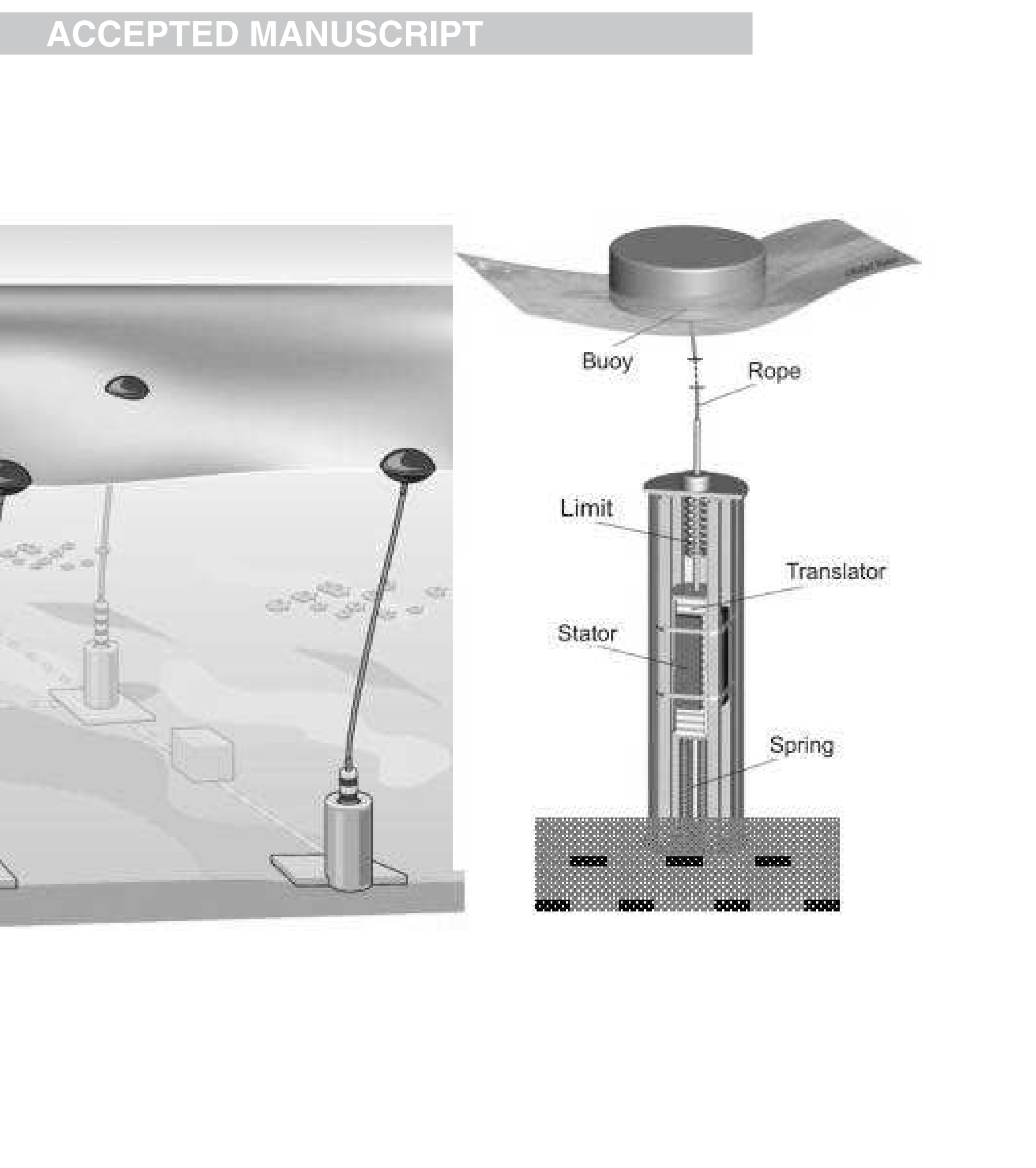

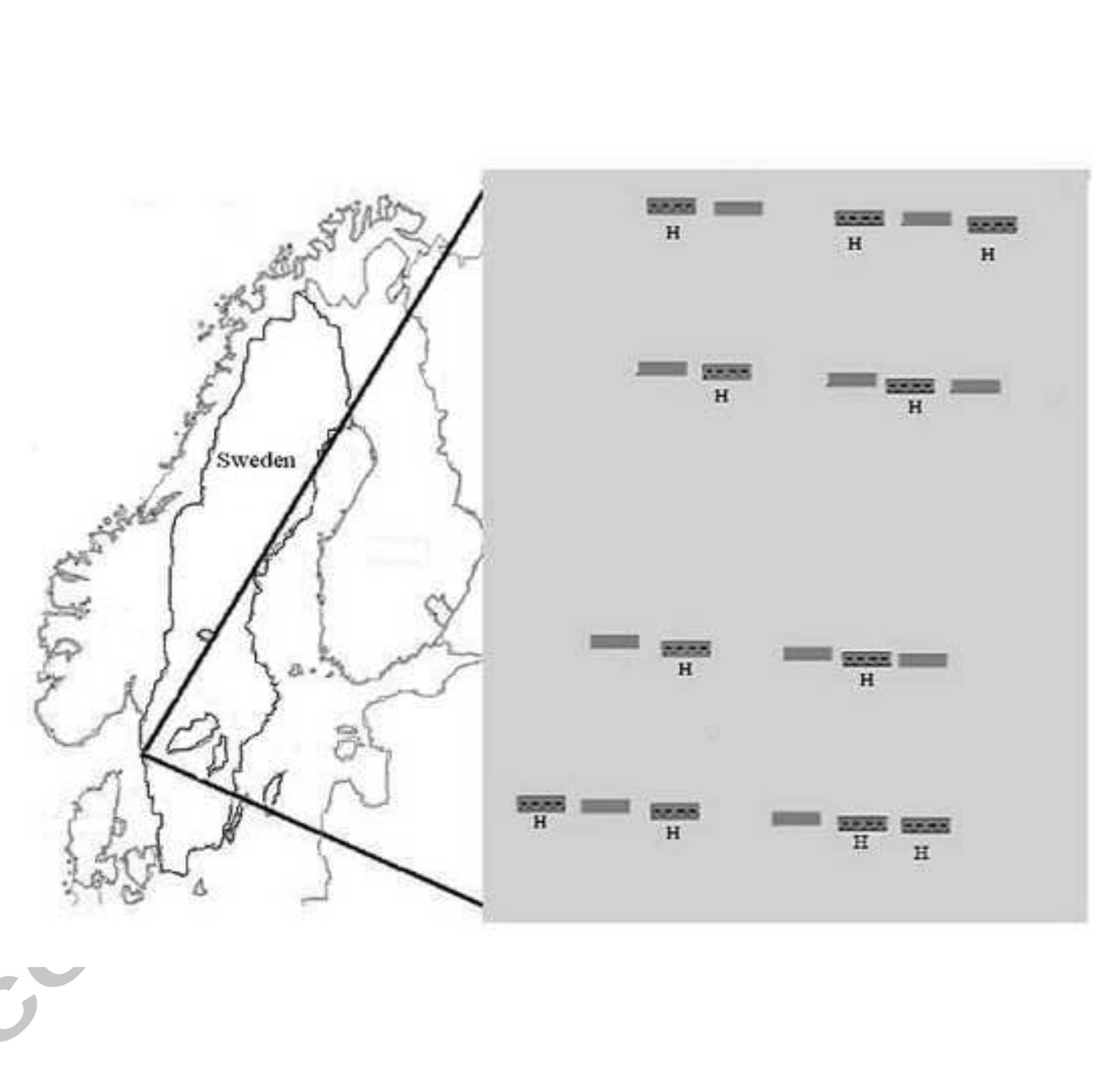

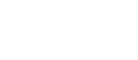

-

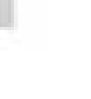




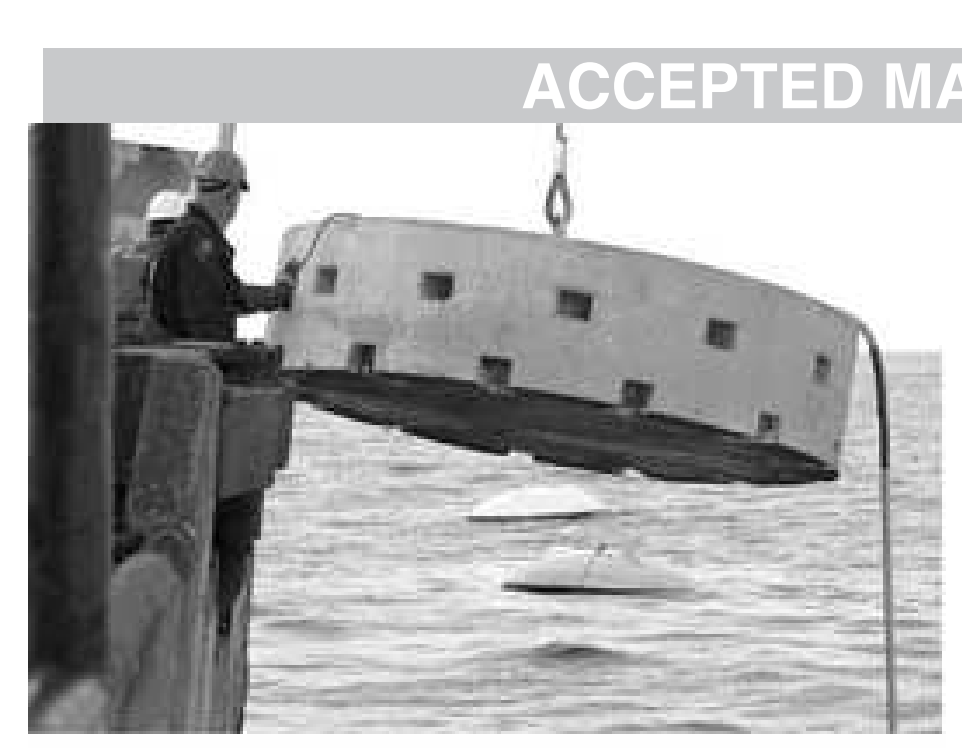

ACCEPTED MANUSCRIPT

Figure
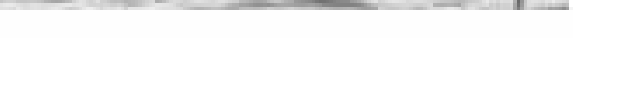


\section{ACCEPTED MANUSCRIPT}

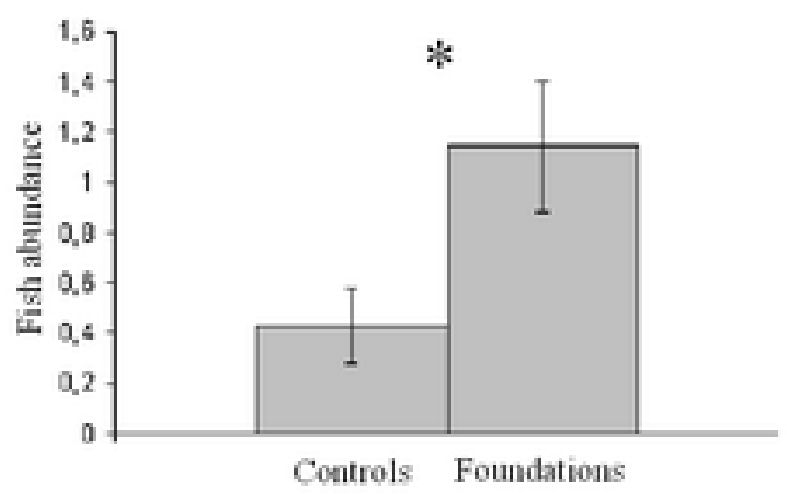

Figure

Controls Foundations 


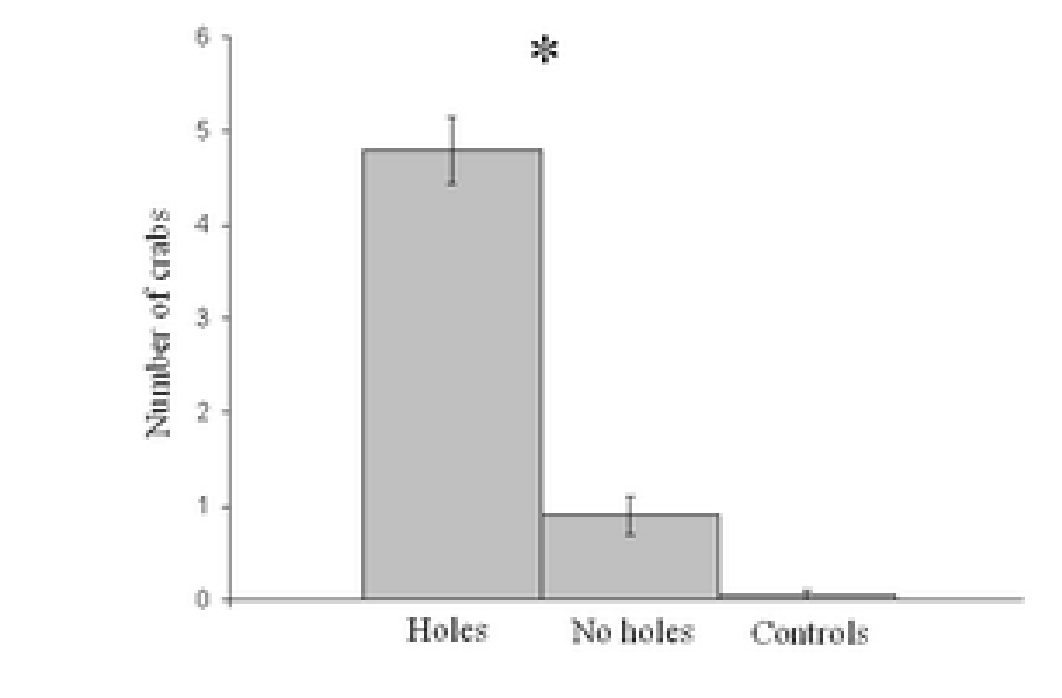

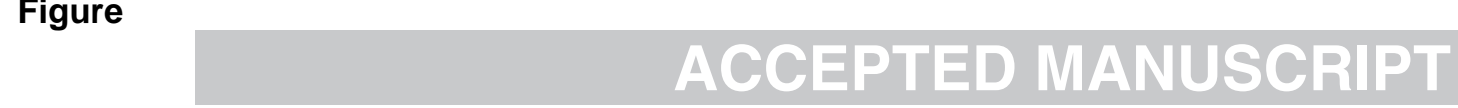

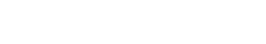




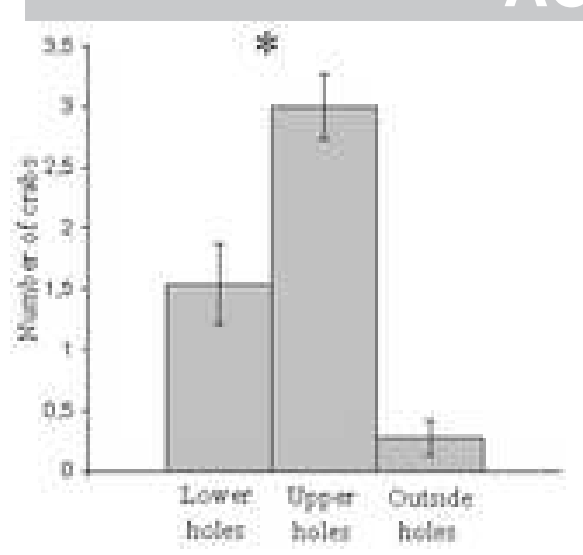

